starting to become reality. It is still too early to tell what the final effects will be, but major agencies are collecting data on how sequestration is affecting their grant recipients. Some are also taking the informal route: National Institutes of Health head Francis Collins, for instance, put out a Twitter request for stories at \#NIHSequesterImpact. Tales flooded in of grants cut, delayed or denied altogether, to the point that lab heads are hiring fewer staff and delaying purchasing major equipment or other supplies.

Of course, it is hard to know which effects result from the sequestration and which are caused by general financial belt-tightening. But Washington's inability to reach a budget deal underlies nearly all the economic uncertainty plaguing US science agencies today. The last time Congress passed a proper budget was for fiscal year 2012, which ended last September. Since then, agencies have been operating on temporary, unsettled numbers, topped by a roughly $5 \%$ slash from sequestration. Then Obama was two months late in releasing his proposed budget for fiscal year 2014 (see Nature 496, 277-279; 2013). Even seasoned budget wonks call the current situation the worst in recent memory.

As uncertainty swirls around the future, budget sequestration is hitting science agencies now. Some of the earliest and most drastic cutbacks have come in the field of Earth monitoring (see page 419). A small fraction of the 8,000 national streamflow gauges are being shuttered, because the US Geological Survey (USGS) can no longer pay its share of the bills. Surveys of western America's snowpack are also being slashed, eliminating crucial information about the water supply for many mountain states. All this is happening as wildfire season kicks off and as sequestration thins the ranks of federal firefighting teams. Meanwhile, the

Pavlof volcano in Alaska began erupting on 13 May, even as cutbacks at the Alaska Volcano Observatory mean that scheduled maintenance of seismic stations at remote volcanoes in the state is not carried out. Without seismic monitoring at many of these mountains, the USGS is, in essence, blind to some future eruptions.

Federal managers insist that crucial measurements will continue to be made. The National Oceanic and Atmospheric Administration

"Even seasoned budget wonks call the current situation the worst in recent memory."
(NOAA) plans to impose at least four days of unpaid leave through the summer. But officials say that mission-crucial operations will be unaffected. That includes forecasting severe storms, such as the tornadoes that swept across much of the nation's mid-section this week, as well as Atlantic hurricanes for which the season begins on 1 June.

One can only hope that NOAA means it. Weather forecasting is expensive because it demands trained personnel. These are the same people who are being told to take unpaid leave, then do double duty when they return to work. Such incessant cutting can go on for only so long before morale suffers.

Already, programme managers at agencies such as the USGS and NASA are taking near-heroic steps to keep funding flowing to monitoring projects, shuffling money between programmes. But in the process they are mortgaging much of their future, by cutting back on savings for longer-term expenses such as upgraded computer servers or more personnel. Let us hope that Congress relieves the agencies, and soon, by getting its budgetary house in order.

\section{Shades of grey}

\section{It is risky to oversimplify science for the sake of a clear public-health message.}

W ho knows how many New Year's resolutions to diet were strangled at birth by Katherine Flegal? A group led by Flegal, an epidemiologist at the US National Center for Health Statistics in Hyattsville, Maryland, published a paper on 2 January that suggested that a bit of extra weight may be no bad thing (K. M. Flegal et al. J. Am. Med. Assoc. 309, 71-82; 2013). In fact, the study - and the media coverage it generated - indicated that people deemed 'overweight' live longer than those who could fit into a pair of jeans a size or two smaller.

As we explore in a News Feature on page 428, the study was not the final word on the matter. Opponents have lined up to criticize the research and its findings. Walter Willett, chair of the nutrition department at the Harvard School of Public Health in Boston, Massachusetts, told US National Public Radio that "this study is really a pile of rubbish, and no one should waste their time reading it".

Critics of Flegal and of others who have reported similar findings take issue not just with the data used to make the claims, but the damage they feel that the claims will inflict on public-health efforts. It is much easier to gain weight than to lose it, and nobody disputes that to gain too much weight - to be obese - is bad for health. To discuss publicly results that threaten to undermine the simple message that 'fat is bad' will confuse doctors and the public, the critics say.

The debate goes beyond the health effects of weight. Just last week, the US Institute of Medicine issued a report that threatens to confuse doctors and the public on the issue of how much salt is bad for one's health. Convention holds that too much salt is harmful, and that the best approach is to reduce and limit intake as much as possible. Yet some studies show that some people can eat too little salt. Low sodium intake is also associated with poorer health in groups such as the over 50 s and those with diabetes. However, too much salt remains bad for

health, the report said, as it increases the risk of heart disease. The simple message on salt, unfortunately, is that it can be good or bad for people, depending on who they are.

The political mantra on public-health advice is clear: don't send mixed messages. The media and those who get their information from the media prefer things in black and white: red wine is good for you; chocolate is bad for you. But, of course, science does not deal in black and white, hence the common criticism that scientists cannot make up their minds. One week, one group argues that extreme exercise is positive for health; the next week, a different set of researchers says the opposite.

Scientists like to believe that they can operate in shades of grey. But simple messages and themes are seductive. In the public-health and nutrition fields, the idea that excess weight might benefit health is called the 'obesity paradox' despite the fact that it does not focus on obesity, which everyone agrees is bad, and so is not a paradox. The 'mildly overweight paradox', presumably, sends mixed messages. When Willett dismissed the Flegal study as a "pile of rubbish" there were no shades of grey evident.

The problem with simple messages and black-and-white statements is that they tend to be absolutes and so the easiest to falsify. The line that the science of global warming is 'settled' must have seemed like a good idea at the time, and when taken to refer to the narrowest of scientific questions it is correct, but it was (fairly) interpreted as insistence that no queries remained. Even legitimate debates on outstanding issues - climate sensitivity, say - can now be painted as unsettling not just to the scientific position, but also to the policy response it demands.

It is easy to see why those who spend their lives trying to promote the health of others gnash their teeth when they see complex findings whittled down to a sharp point and used to puncture their message. It is more difficult, from a scientific perspective, to agree that these findings should not be published and discussed openly, warts and all, purely because they blend uncertainty into a simple mantra. Make

$\rightarrow$ NATURE.COM To comment online, click on Editorials at: go.nature.com/xhunqv things as simple as possible, Einstein said, but no simpler. And simple, black-and-white messages can cause confusion of their own. All things in moderation - and that should include the language we use. 